Short Communication

\title{
Influence of Pseudomonas aeruginosa and Sulfate-reducing bacteria composite on the corrosion behavior of brass
}

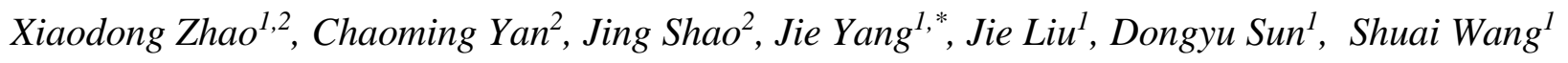 \\ ${ }^{1}$ School of Ocean, Yantai University, Yantai 264005, China; \\ ${ }^{2}$ School of Naval Architecture and Mechanical-electrical Engineering, Zhejiang Ocean University, \\ Zhoushan 316022, China \\ *E-mail: kittyangj@163.com
}

doi: $10.20964 / 2019.07 .19$

Received: 11 March 2019 / Accepted: 22 April 2019 / Published: 10 June 2019

\begin{abstract}
In this paper, electrochemical methods such as open circuit potential(OCP) and electrochemical impedance spectroscopy(EIS) were used to assess the corrosion behavior of brass in sterile water and media containing Pseudomonas Aeruginosa, sulfate-reducing bacteria and their bacteria composite, respectively. The results showed that corrosion occurred to some extent in all the media. The corrosion rate of brass in the Pseudomonas Aeruginosa system is lower than that in the sulfate-reducing bacteria system. Especially in single Pseudomonas Aeruginosa system, the open circuit potential and total impedance value were comparatively higher than those in the other systems. In addition, the acceleration of corrosion in the composite system began from the 3rd day, later than that in the single sulfate-reducing bacteria system, indicating that the presence of Pseudomonas Aeruginosa might inhibit the activity of sulfate-reducing bacteria.
\end{abstract}

Keywords: Microbiologically influenced corrosion (MIC); Sulfate-reducing bacteria; Pseudomonas aeruginosa; Electrochemical impedance spectroscopy (EIS)

\section{$\underline{\text { FULL TEXT }}$}

(C) 2019 The Authors. Published by ESG (www.electrochemsci.org). This article is an open access article distributed under the terms and conditions of the Creative Commons Attribution license (http://creativecommons.org/licenses/by/4.0/). 